\title{
Development CPS integrated TPACK model to improve student problem solving in new normal pandemic COVID-19
}

\author{
Edy Waluyo ${ }^{*}$, Nuraini ${ }^{1}$ \\ ${ }^{1}$ Hamzanwadi University, Indonesia \\ 函edywaluyo@hamzanwadi.ac.id*
}

\section{Article Information \\ Submitted March 23, 2021 \\ Revised April 24, 2021 \\ Accepted April 27, 2021}

\section{Keywords}

CPS;

Problem Solving;

TPACK.

\begin{abstract}
In $21^{\text {st }}$-century learning, teachers must integrate technology, pedagogy knowledge, and content to improve students' problem-solving skills. Through problem-solving, students are required to think systematically, critically, logically, and have an unyielding attitude to find solutions to problems. This study aims to develop CPS integrated TPACK model to improve problem-solving capabilities. Borg \& Gall model development research uses the research method, including needs analysis, product design, product development, product implementation, and evaluation. Data analysis was used in this study using descriptive analysis. Based on the data analysis conducted, the average product validation score of 3 experts in a row was $79.4 ; 79,9$; and 80.8 in the valid category. The products developed are also relatively practical, with an average practical score of 82.67. The product trials were conducted four times the meeting showed that the products used are classified as pragmatic. The product is classified as effective with an effectiveness percentage of $86.67 \%$, so it is feasible to be implemented. The product developed has a potential effect in the high category to improve math problem-solving skills with an N-Gain of 0.81 .
\end{abstract}

\section{INTRODUCTION}

The development of science and technology in the 21st century in the adaptation of new habits during the current covid-19 pandemic has changed the characteristics of learners so that it requires innovative orientation and learning methods. In today's 21 st century learning, it is necessary to do such learning so that every student who has a high level of thinking ability, problem-solving ability, communication ability, and mathematical thinking ability can face global challenges (NCTM, 2000). Formal education in Indonesia today still emphasizes lowlevel thinking and rarely habituated students to use high-level thinking in dealing with and solving real problems in daily life (Yanti, 2019). Students' thinking ability in mathematics learning is still low because the learning process conducted by teachers has not facilitated learners to explore new ideas and new ideas and only memorize fact facts in mathematics instead of emphasized the development of student thinking (Mahmudi, 2009). TIMSS results in 2015 stated that the results of the mathematics study of Indonesian students ranked 44th out of 49 countries with an average score of 397 (Mullis, 2016).

Meanwhile, PISA studies in 2015 in Indonesia showed that the high level of thinking skills that students have can still be relatively low (OECD, 2016). Related to the above, to overcome the problem can be done such a learning process so that there is a process of structuralization of learning activities involving students in solving the problems given that eventually, students can choose the right way to solve the math problems they face (Khaulah, 2018; Siswono, 2016). In high-level thinking, students are required to explore new ideas, 
insights, and ideas to solve problems faced, so that in the learning process in class, teachers are required to be able to design learning that can train and develop high-level thinking skills of learners (Waluyo, 2021).

Students' thinking skills can be developed through problem-solving (Waluyo et al., 2020). One of the mathematical skills that students must have is problem-solving skills. However, problem-solving skills are complex for students to achieve in following the learning process. The activity of learning problems that are considered problematic by students is to demand problem-solving skills (Khatimah, 2019). This is because students learn only according to the example given by the teacher so that when given non-routine questions, students will experience mistakes. Through the problem-solving process, students must think systematically, critically, and logically to find solutions to the math problems encountered. Problem-solving as an individual skill is the process of analyzing, interpreting, reasoning, predicting, evaluating, and reflecting on the problems to be solved. Problem-solving is everyone's ability to use their knowledge in finding solutions varies depending on what they see, observe, and in their minds according to real-life events (Endah, 2019). Problem-solving is an intellectual activity in finding solutions or solutions to problems involving knowledge, insight, and experience (Maimunah, 2016). Problem-solving is an ability to use previously owned or known knowledge to solve problems (Ulya, 2016). Problem-solving skills are an essential aspect of mathematics learning today and in the future. Through problem-solving skills, students are trained to be able to construct knowledge to be able to relate to other fields of science, encouraging students to think so that they can see many possible solutions to a problem with an acuity of observation, analysis, and development of problem-solving process (Rahmani, 2018). It is necessary to develop problem understanding skills, create mathematical models, solve problems and interpret the solutions (Hidayat, 2018). Problem-solving skills are the potential students have in solving story problems, solving problems that are not routine, and applying mathematics in daily life to find solutions or solve problems in mathematics (Andayani, 2019). The problem-solving steps are understanding the problem, planning to solve problems, solving the problem, and rechecking all the steps that have been done (Nur \& Palobo, 2018). Meanwhile, indicators of mathematical problem-solving skills include (1) identifying known, questioned elements, and adequacy of necessary elements, (2) formulating mathematical problems or putting together mathematical models, (3) applying strategies for solving mathematical problems, (4) explaining results according to real problems, and (5) using mathematics meaningfully (NCTM, 2000). Based on the steps and problem-solving, students will try to find the right solution to solve the problem.

One of the learning models that need to be passed by teachers that involve students actively in learning and can improve the ability to solve mathematical problems is Creative Problem Solving (CPS). CPS model is one of the models of problem-solving development that is considered adequate and can help solve various problems in daily life (Ismiyanto, 2010). CPS learning model is a learning model that focuses on learning and problem-solving skills, followed by strengthening skills (Effendi \& Fatimah, 2019; Hariawan, 2014; Nur et al., 2017; Paryanto, 2020; Nursiami, 2015; Sugianto, 2018; Turmuzi, 2018). CPS is functions to improve the thought process so that it is better able to overcome difficulties (Puccio, 2005). CPS that facilitates the problem-solving approach of specific problems will prepare space for increased creativity in problem-solving (Adams, 2015). Learning with the CPS model provides teachers with the opportunity to motivate, encourage, and optimize each other's 
knowledge and master the skills delivered by teachers (Bahrudin, 2020). So that students are more accessible or free to think, respond and help each other (Pramestika, 2020). In CPS, previous experience in solving a problem is an essential factor in solving different new issues. When students are faced with a problem, they can do problem-solving skills to select and develop their ideas and thoughts. Students not only use a way of memorizing without a thought process but use problem-solving skills that develop a high level of thought process (Pepkin, 2014)

The CPS process follows the steps: (1) clarifying the problem, namely explaining to students about the problem so that students can understand what kind of resolution is expected; (2) disclosure of opinions, students are freed to express opinions on various problem-solving strategies; (3) evaluation and selection, each group discusses which opinions or strategies are suitable for solving problems; (4) implementation, students, determine which strategies can be taken to solve the problem, then apply it until finding a solution of the problem (Muslich, 2007). (Huda 2014) suggests that the steps of the CPS learning model are, first, objective finding, where students are divided into groups to discuss the situation of problems raised by teachers. The second step is fact-finding, where students brainstorm all facts related to the problem. The third step is problem finding, to redefine the problem so that the student is closer to the problem to allow him to find a more straightforward solution. The fourth step is idea finding, where students' ideas are listed to see the possibility of becoming a solution to the problem situation. The fifth step is solution finding to evaluate ideas that have the most significant potential to solve problems. The sixth meeting is acceptance finding, where students begin to consider fundamental issues with a way of thinking that has already started to change. Based on the steps of the CPS learning model above, students are trained to think systematically and logically, think critically in solving problems, communicate ideas, and train students to interact with each other through group activities. The CPS model can improve the ability to think critically and creatively in solving problems faced by students. The increasing ability to think critically and creatively about the problems learned allows students to solve problems more efficiently.

The development of information and communication technology has had a significant influence on the learning process. The 21 st century encourages teachers to have knowledge related to information and communication technology. Teachers must have technological knowledge, Pedagogical, Content Knowledge (TPACK) that can integrate technology in learning, let alone learning in schools today must follow the adaptation of new habits due to the covid-19 pandemic. Technological pedagogical content knowledge (TPACK) is one of the new types of knowledge that teachers must learn to integrate technology well in learning (Mishra \& Koehler, 2006). TPACK transforms knowledge, content, and pedagogical knowledge into different types of knowledge used to develop and implement teaching strategies (Tuithof, 2021). Technological Pedagogical Content Knowledge is a knowledge of how various technologies can be used in learning, and the use of such technologies can change the way teachers teach (Farikah, 2020). Teachers must actively participate in technology integration and have several competencies to use the technology available in the learning environment appropriately and effectively (Akturk, 2019). TPACK is the intersection of the three bodies of technological knowledge, pedagogy, and content affecting and limiting the context of learning and teaching (Rahmadi, 2020). The determining factor of TPACK for all components is integrated with ICT so that TPACK contributes significantly to the 
paradigm change of learning (Malik, 2018). TPACK has become a framework or framework that can be used to analyze teacher knowledge related to integrating technology in learning (Koehler, 2013). Based on this understanding, Technological Pedagogical Content Knowledge (TPACK) is about using technology in appropriate academic to teach a particular content well. TPACK is a teacher's knowledge of when, where, and how to use technology. Therefore, teachers must improve their knowledge and skills in a particular field of study and integrate with technology for a specific framework or learning model. In addition, teachers should be able to use the right technology on pedagogics appropriate for explicit content.

TPACK integrated CPS learning model is a CPS learning model wherein every step of learning is combined with technology such as LCD, android, google drive applications, power points, and Other. Step learning model CPS integrated learning model TPACK includes: (1) Orientation of real problems that are giving explanations to students about the problems raised, through the google drive application; (2) disclosure of opinions, students are freed to express opinions on various problem-solving strategies by digging information through the internet and their android; (3) evaluation, each group discusses which opinions or strategies are suitable for solving problems with one of the students documenting with their android; (4) implementation, students determine strategies that can be suitable to solve problems and find solutions to problems by accessing the required information with their android; (5) students present the results of the activity in the form of power points; (6) the teacher evaluates the student's discovery activities and gives conclusions based on the results of the student's activities. This is supported by research conducted by (Suyamto, 2020), stating that TPACK describes the different types of knowledge teachers need to teach using certain strategies such as CPS effectively with the help of technology. Similarly, research conducted by (Rahmadi 2019) stated that the use of learning strategies in the entire teacher education program is a step to integrate TPACK in learning more comprehensively. Furthermore, the use of information technology-assisted CPS models affects problem-solving capabilities (Partayasa, 2020). This study aims to develop CPS integrated TPACK model to improve problem-solving abilities. Learning in the 21 st century and during the current pandemic covid-19, teachers must choose specific strategies in teaching certain materials by integrating technology in learning. During the current pandemic covid-19, where most of the teaching is done online, using learning strategies that are integrated CPS model TPACK is believed to improve students' motivation and problem-solving skills. Therefore, CPS integrated TPACK can be used as alternative learning in the new era of normal pandemic covid-19 as it is today.

\section{METHODS}

The research method used is development research which is a process carried out in developing an educational product, including needs analysis, product design, product development, product implementation, and evaluation (Dick \& Carey, 2001), as presented in Figure 1 below. 


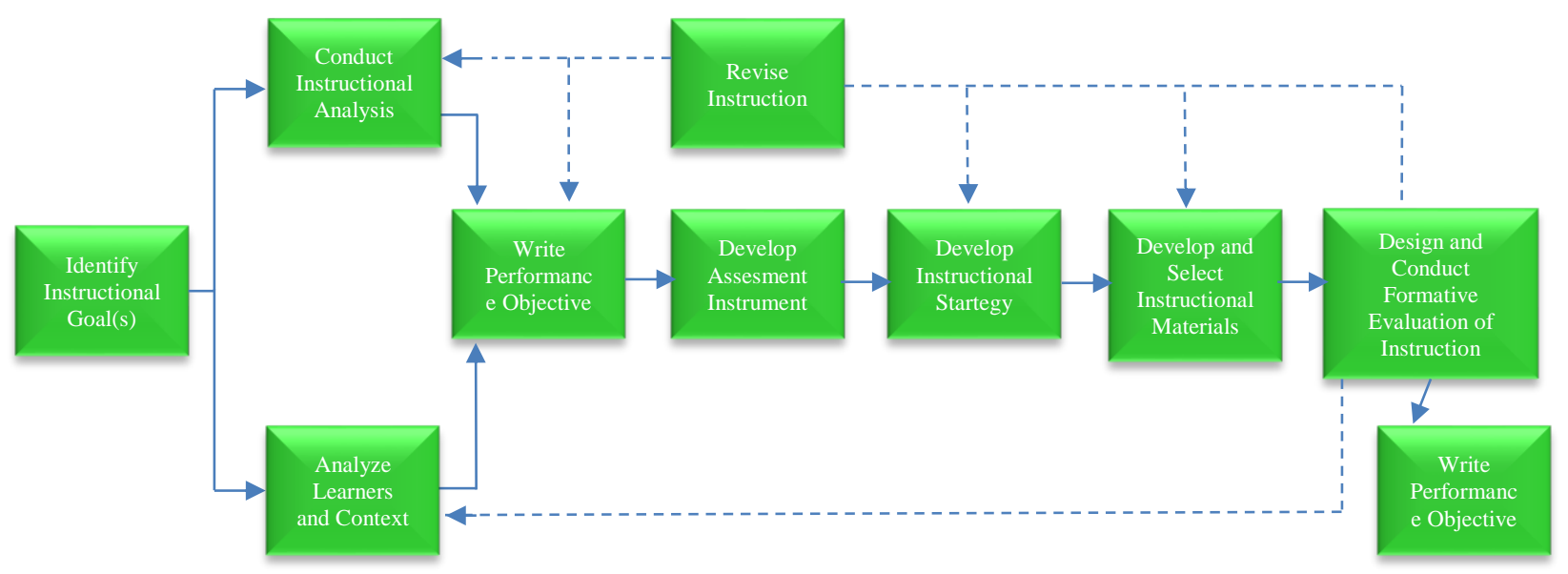

Figure 1. Dick \& Carey's Development Model

The subjects of this study were grade VIII students of SMPN 2 Selong, which numbered 30 students. The research instrument as a data collector consists of guidelines or validation sheets, a questionnaire of the practicality of learning implementation, and a test of problemsolving skills. The validation guidelines consist of 12 questions with measurement indicators, including the formulation of learning objectives, content, language, and time. The product practicality questionnaire consists of 10 questions with hands, including feelings of pleasure towards the learning component, novelty, interest. The test results learn about problemsolving skills in the form of essay tests with indicator 1) understand the problem; 2) develop a strategy or settlement plan; 3) solve the problem according to the plan that has been made, and 4) re-examine the answer (Winarti, 2017). Product validation is carried out by three validators in education, namely material experts and linguist learning technology experts.

The quality of the development product in the form CPS learning integrated TPACK model in this study is based on the criteria of validity, practicality, and product effectiveness. The learning model is valid if there is an association between the characteristics of the learning model used and each component of the developed learning model. The product produced is said to be valid if it meets the established eligibility criteria. Testing the practicality of the product developed is measured from two aspects: based on the assessment of experts and teacher response after going through operational trials in the field. The validation guidelines grid is presented in the following Tables 1 and 2.

Table 1. Product Validation Guidelines for Material Experts

\begin{tabular}{ll}
\hline Aspects & Indicators \\
\hline Conformity & Conformity of learning model with learning competency and \\
student development level \\
Ease of use & Easy-to-understand language and easy-to-use learning model by \\
& teachers \\
Completeness & Completeness of materials and exercises of questions and select \\
& technology applications ( google drive, PowerPoint, android, \\
Clarity & etc.) \\
& Clarity of description and systematic arrangement of materials in \\
the learning model
\end{tabular}


Table 2. Product Validation Guidelines for Technology Experts

\begin{tabular}{ll}
\hline Aspects & \multicolumn{1}{c}{ Indicators } \\
\hline Kesesuaian & $\begin{array}{l}\text { Accuracy in the selection of technology based on the purpose } \\
\text { of learning and characteristics of learners, as well as accuracy } \\
\text { in the section of material content }\end{array}$ \\
& $\begin{array}{l}\text { Easy to use by teachers } \\
\text { Ease }\end{array}$ \\
The language used is easy to understand, and the selection of \\
technology for easy-to-use learning by students.
\end{tabular}

The validation and practical instrument used to measure the validity and practicality of the learning model developed is the CPS integrated TPACK model that has been developed using criteria such as Table 3 below (Waluyo et al., 2020).

Table 3. Criteria for Validity

\begin{tabular}{cl}
\hline Interval Score & Criteria \\
\hline $85<\mathrm{X}$ & Very Valid/Very Practical \\
$70<\mathrm{X} \leq 85$ & Valid/Practical \\
$\mathrm{X} \leq 70$ & Invalid/Impractical \\
\hline
\end{tabular}

Testing the effectiveness of the developed product was conducted by looking at the student's posttest score on the student's problem-solving skills after following the learning. Product effectiveness indicators are determined by the criteria of at least $85 \%$ of the number of students given tests on problem-solving skills get a minimum score of 75. As for testing whether the product developed has a potential effect in improving problem-solving skills, students are done by calculating the magnitude of $\mathrm{N}$ - Gain by using the design of One Group Pretest Posttest Design.

\section{RESULTS AND DISCUSSION}

The research began with analyzing the needs conducted by interviewing math teachers to know the characteristics of learning undertaken by teachers at SMPN 2 Selong. The results of interviews with 3 math teachers can be concluded that (1) most of the learning process is still conventional and has not been centered on students, where the teacher only explains and explains the lesson material, and continues with the example of the question and then gives exercises similar to the problem that has been explained has not emphasized on the development of thinking and problem solving skills; (2) Teachers have not utilized technology and information optimally in developing learning devices such as laptops, LCD, google drive applications and others as the demands of 21st century learning; (3) Teachers need facilities prepared by the school in the form of facilities and infrastructure such as laptop, LCD and internet networks that are adequate in integrating technology in learning; (4) Teachers expect support from the school to increase their knowledge in the field of technology and information as part of the competencies required in carrying out current learning. Meanwhile, based on the questionnaire given to 20 students of grade VIII SMPN 2 Selong, the learning obtained shows that (1) the learning obtained in general has not been fun and boring and impressed that mathematics is still considered as one of the problematic and scary lessons; (2) in learning, the teacher's efforts to develop the student's math problem solving skills are not optimal so that the student's math problem solving skills are still low, judging by the after-learning exercises that show the student is only able to solve the problem if the problem has the same shape as the example given; (3) the utilization of technology in learning by both students and teachers is still low, this is due to the lack of facilities prepared 
by the school and the economic ability of the parents to prepare facilities such as android; (4) students feel that in learning the teacher has not fully applied the learning that can develop thinking skills and problem solving skills so that the learning is monotone. Thus, it is necessary to develop a learning model that engages students actively in learning to develop high levels of thinking skills and math problem-solving.

The product in the form of CPS learning model is developed according to the stages of CPS integrated TPACK activities, namely how teachers integrate between pedagogical knowledge that is what teachers know about teaching, namely the application of CPS learning to the understanding of what lessons teachers know by utilizing information technology such as LCD, laptop, google drive applications and other applications that are appropriate to the learning used. The learning stages of the learning model with CPS integrated TPACK developed include: (1) The orientation of the real problem is the explanation to the student about the problem raised, through the google drive application; (2) disclosure of opinions, students are freed to express opinions on various problem-solving strategies by digging information through the internet and their android; (3) evaluation, each group discusses which opinions or strategies are suitable for solving problems with one of the students documenting with their android; (4) implementation, students determine strategies that can be suitable to solve problems and find solutions to problems by accessing the required information with their android; (5) students present the results of the activity in the form of power points; (6) the teacher evaluates the student's discovery activities and gives conclusions based on the results of the student's activities. In the current era of new normal pandemic covid-19, teachers can do the above learning model online using certain learning flatforms such as zoom, google meet, and others.

Three experts validated the product draft: learning materials experts, learning technology experts, and linguists. Expert validation is performed to obtain responses, suggestions, comments, and corrections to the initial product to improve product quality further. Based on the validity criteria of the product as in Table 3, the validation results of the experts show that the overall product developed belongs to a valid category and is presented in Table 4 below.

Table 4. Product Validation Results by the Experts

\begin{tabular}{llll}
\hline \multirow{2}{*}{ Components } & \multicolumn{2}{l}{ Validation Results } & \\
\cline { 2 - 4 } & Validator I & Validator II & Validator III \\
\hline Identity & 90 & 92 & 90 \\
Goal formulation & 85 & 83 & 84 \\
Formulation of indicators & 75 & 78 & 73 \\
Material suitability & 80 & 78 & 78 \\
Learning Strategies & 80 & 81 & 83 \\
Learning Activities & 85 & 83 & 84 \\
Technology Electability & 75 & 78 & 79 \\
Technology Integration & 70 & 72 & 76 \\
Assessment & 76 & 81 & 82 \\
Language Usage & 78 & 73 & 79 \\
Average Score & 79,4 & 79,9 & 80,8 \\
Conclusion & Valid & Valid & Valid \\
\hline
\end{tabular}

Based on the expert validation results in Table 4 above, the average product validation score of the three experts in a row is $79.4 ; 79,9$; and 80.8 in the valid and eligible category to proceed at the field trial stage. 
The practicality of the product developed is based on the assessment score of the practicality questionnaire by the opinion of experts and the implementation of learning by teachers using products developed using established practicality criteria. Based on the data obtained from the observation sheets collected, both observation sheets by experts and respond teachers and students are presented in Table 5.

Table 5. Experts' Practicality Assessment Results

\begin{tabular}{llr}
\hline Validator & Practicality & Category \\
\hline Validator I & 84 & Practical \\
Validator II & 82 & Practical \\
Validator III & 82 & Practical \\
Average & 82.67 & Practical \\
\hline
\end{tabular}

Based on the validation results of experts both by validators I, II, and III and the average results of validation shows that the CPS integrated TPACK model developed is relatively practical. While the practicality of the product based on the implementation of learning conducted by mathematics teachers using the designed products is presented in the following Table 6.

Table 6. Observers' Practicality Assessment Results

\begin{tabular}{lllll}
\hline \multicolumn{1}{c}{ Assessment Aspects } & $1^{\text {st }}$ Meeting & $2^{\text {nd }}$ Meeting & $3^{\text {rd }}$ Meeting & $4^{\text {th }}$ Meeting \\
\hline Delivery of learning indicators & 85 & 81 & 82 & 84 \\
Motivating Students & 83 & 86 & 81 & 82 \\
Real Problems & 82 & 84 & 79 & 74 \\
Mastery of materials & 82 & 80 & 78 & 75 \\
Mastery of technology & 78 & 81 & 81 & 79 \\
Accuracy of learning syntax & 79 & 75 & 76 & 78 \\
Technology integration & 81 & 78 & 79 & 82 \\
Evaluate & 84 & 82 & 82 & 81 \\
Class management & 85 & 83 & 78 & 78 \\
Formulating Conclusions & 76 & 82 & 75 & 75 \\
Average Score & 81.5 & 81.2 & 79.1 & 78.8 \\
Conclusion & Practical & Practical & Practical & Practical \\
\hline Table 6 a & & applying & learn using & CPS integrated TPACK
\end{tabular}

Table 6 above shows that after field trials, applying to learn using CPS integrated TPACK model for four meetings shows that the learning model used in learning falls into the practical category in all sessions.

The product's effectiveness is the CPS integrated TPACK model seen from the students' pretest and posttest scores on mathematical problem-solving skills in geometry materials. The test on problem-solving skills was given to 30 students of grade VIII SMPN 2 Selong. Scores of pretest results and posttest math problem-solving skills of students of geometry material are shown in Table 7.

Table 7. Pretest Scores and Student Problem Solving Skills Posts

\begin{tabular}{llllllc}
\hline \multirow{2}{*}{ Indicator } & \multicolumn{3}{l}{ Average Score } & \multicolumn{2}{c}{ Number of students } & Percentage \\
\cline { 2 - 7 } & $\begin{array}{l}\text { Pretes } \\
\mathbf{t}\end{array}$ & $\begin{array}{l}\text { Postes } \\
\text { t }\end{array}$ & $\begin{array}{l}\boldsymbol{N} \text { - } \\
\text { Gain }\end{array}$ & $\begin{array}{l}\text { Complete } \\
\text { (score } \geq 75)\end{array}$ & $\begin{array}{l}\text { Incomplete } \\
\text { (Score } \\
<\mathbf{7 5}\end{array}$ & $\begin{array}{l}\text { Students } \\
\text { Complete }\end{array}$ \\
\hline Understand the problem & 34.75 & 87.39 & 0.81 & & & \\
Develop a strategy & 37.67 & 86.67 & 0.79 & 26 & 4 & 86.67 \\
Resolve issues & 34.84 & 89.21 & 0.83 & & & \\
Re-examine an answer & 37.52 & 87.37 & 0.80 & & & \\
Average Score & 36.28 & 87.66 & 0.81 & & & \\
\hline
\end{tabular}


Based on Table 7 above, it can be seen that out of the 30 students of grade VIII SMPN 2 Selong who were given tests on math problem-solving skills of geometry material, there were 26 students or $87.67 \%$ who got a test score $\geq$ of 75 and only four students who did not complete that got a test score of $<75$. It can be concluded that the number of total students is $87.67 \%$ meets the criteria for implementation of the learning model applied, which is at least $85 \%$. Thus the product developed is a learning model CPS integrated TPACK effective for use.

Further testing whether the learning model developed potential in improving students' problem-solving skills is determined based on the N-Gain score that is the difference the student's problem-solving ability of geometry material between pretest and postest field test results. Field trials were conducted during four meetings for grade VIII students of SMPN 2 Selong. The test results presented in table 7 above show that the $\mathrm{N}$-Gain value for the understanding aspect of 0.81 belongs to the high category. The completion strategy of 0.79 belongs to the high class, the problem-solving component of 0.83 belongs to the high sort. The recheck aspect of 0.80 belongs to the high category. Similarly, when viewed from the four indicators, the $\mathrm{N}$-Gain value of 0.81 belongs to the high class. This shows that the implementation of the CPS integrated TPACK model can improve the problem-solving skills of the high category.

Learning with the CPS model begins with the provision of real problems by teachers that students must solve. Students are then tried to play an active role in conveying their ideas and ideas to solve the problem through active discussions both in groups and between groups. Discussions in groups are intended to pour ideas and ideas and experiments into solving problems, and then students present the results of solving their problems. A series of activities ranging from problem-giving to presentation of findings or problem solving, both teachers and students utilize information technology that corresponds to each stage of the series of learning activities such as using laptops and LCD for presentations, google drive application to send real problems that students have to solve as well as an android that students use to dig up various information used to solve the problem. This learning activity series fosters high levels of thinking skills and curiosity of students and is also thought to improve students' math problem-solving skills. The active involvement of students is believed to create interest so that students are interested in learning the material that will be delivered by the teacher (Andana, 2014). Learning with the CPS model allows students to discuss in groups to develop mathematical problem-solving skills. Knowing with the CPS model will enable students to explain how they express their opinions or ideas and determine strategies for problem-solving (Muhammad, 2018).

The use of technology in learning affects what is taught and when a learning material appears in a curriculum. Teachers need to ensure that the use of technology in education is effective. In addition, teachers should use technology to increase students' chances of constructing their knowledge by choosing or creating mathematical tasks that can take advantage of what the technology can do well and effectively (NCTM, 2000). Teachers also need to understand when to use technology, how to use technology, and what impact result from the use of technology in learning. When choosing to use technology as part of learning, teachers should understand the elements and implications of using technology related to teaching, management, content (material), pedagogic, and technology itself (Guerrero, 2010). Integration of technology, pedagogy, and range in learning tools based on Technology, 
Pedagogy, and Content Knowledge (TPACK) as creative solutions developed in learning (Sutrisno, 2012). TPACK based learning tools optimize students' learning activities and improve students' critical thinking and problem-solving skills (Mairisiska, 2014). TPACK refers to the teacher's ability to transform the material into a pedagogically excellent and adaptive form for various students' skills and backgrounds (Purwaningsih, 2015). TPACK integration in learning with the CPS model can improve students' problem-solving skills because teachers are required to master learning materials and master pedagogic knowledge and master technology. The development of a learning model using the CPS integrated TPACK model impacts students' math problem-solving skills.

\section{CONCLUSIONS}

The product developed in the form of CPS integrated TPACK model has been developed based on needs analysis and systematically developed and refers to the development stage of Borg \& Gall learning model. The product developed has met the product feasibility criteria both in terms of product validity, practicality, and product effectiveness. Validation results show that the product falls into a valid category based on the results of expert assessments or validators of both learning materials experts, learning technology experts, and linguists indicated by the assessment score of the validation sheet of 80.0 each; 79.9 and 80.8 and eligible to continue at the field trial stage. The products developed also fall into the practical category based on practicality assessment scores by three experts using practicality criteria set with consecutive average scores of 84.82 and 82 . Based on the trials, the observations showed that the implementation of learning implementation belongs to the excellent category. The product developed is also relatively effective, demonstrated from the percentage of students who obtained problem-solving skills scores on geometry materials $\geq 75$ by $86.67 \%$.

The learning model developed by the CPS integrated TPACK model also can improve students' mathematical problem-solving skills, shown by the N-Gain score of 0.81 in the high category. Facing 21st-century learning and the new normal era, TPACK integrated CPS learning can be used as an alternative for mathematics teachers. The teachers can incorporate technology and learning online so that learning can still be conducted. Since the subjects of this study are still limited to two schools, it is necessary to conduct further research by involving more significant issues and conducting broader trials so that the instructional model developed can be generalized.

\section{AUTHOR CONTRIBUTIONS STATEMENT}

EW worked as the main drafter in this research. data collection and instrument design assisted by NN.

\section{REFERENCES}

Adams, J., Kaczmarczyk, S., Picton, P., \& Demian, P. (2015). Problem solving and creativity in engineering: Conclusions of a three year project involving reusable learning objects and robots. Engineering Education, 5(2), 4-17.

Akturk, A.O. \& Ozturk, H. . (2019). Teachers ' TPACK levels and students ' self-efficacy as predictors of students ' academic achievement. International Journal of Research in Education and Science(IJRES), 5(1), 283-294. 
Andana, E., Raga, G., Nyoman, S. (2014). Pengaruh model pembelajaran berbasis proyek terhadap hasil belajar IPA siswa kelas IV SD Di Gugus V Kecamatan Tegallalang. Jurnal Mimbar PGSD Universitas Pendidikan Ganesha, 2(1).

Andayani, F., \& Lathifah, A. N. (2019). Analisis kemampuan pemecahan masalah siswa smp dalam menyelesaikan soal pada materi aritmatika sosial. Jurnal Cendikia: Jurnal Pendidikan Matematika, 3(1), 1-10.

Bahrudin, J. (2020). Penerapan model pembelajaran creatif problem solving untuk meningkatkan hasil belajar teknologi layanan jaringan materi ragam aplikasi komunikasi data. Journal of Education Action Research, 4(4), 536-545.

Dick, W, \& Carey, L. (2001). The systematic design of instruction. Boston: Addison Wesley.

Effendi, A., \& Fatimah, A. T. (2019). Implementasi model pembelajaran CPS untuk siswa kelas awal sekolah menengah kejuruan. Teorema: Teori Dan Riset Matematika, 4(2), 89-98.

Endah, D., R., J, Kesumawati, N, \& A. (2019). Kemampuan pemecahan masalah matematis berdasarkan self efficacy siswa melalui logan avenue problem solving-heuristic. Jurnal Nasional Pendidikan Matematika, 3(2), 207-222.

Farikah, \& F. (2020). Technological pedagogical and content knowledge ( TPACK ): The students ' perspective on writing class. Jurnal Studi Guru Dan Pembelajaran, 3(2), 190-199.

Guerrero, S. (2010). Technological pedagogical content knowledge in the mathematics classroom. Journal of Digital Learning in Teacher Education, 26(4).

Hariawan, K., \& Wahyono, U. (2014). Pengaruh model pembelajaran CPS terhadap kemampuan memecahkan masalah fisika pada siswa kelas XI SMA Negeri 4 Palu. Jurnal Pendidikan Fisika Tadulako, 1(2).

Hidayat, W., Sariningsih, R. (2018). Kemampuan pemecahan masalah matematis dan adversity quotient siswa SMP melalui pembelajaran open ended. Jurnal Nasional Pendidikan Matematika, 2(1), 109-118.

Huda, M. (2014). Model-model pengajaran dan pembelajaran. Yogyakarta: Pustaka Pelajar.

Ismiyanto, Syafii, \& S. (2010). Implementasi CPS dalam pembelajaran Menggambar: Upaya Peningkatan Kreativitas Siswa Sekolah Dasar. Imajinasi Jurnal Seni, VI(2), 103-113.

Khatimah, H, Sugiman, S. (2019). The effect of problem solving approach to mathematics problem solving ability in fifth grade. Journal of Physics : Conference Series, 1-7.

Khaulah, S. (2018). Penerapan model pembelajaran jucama dengan menggunakan blok aljabar untuk meningkatkan kemampuan berfikir kreatif siswa pada materi persamaan kuadrat. Jurnal Pendidikan Almuslim, 6(2).

Koehler, M. J., Mishra, P., \& Cain, W. (2013). What is technological pedagogical content knowledge ( TPACK )? Journal of Education, 193(3), 13-19. 
Mahmudi. (2009). Mengembangan kemampuan berpikir kreatif siswa melalui pembelajaran topik pecahan. Seminar Nasional Aljabar, Pengajaran Dan Terapannya.

Maimunah., Purwanto., Sa'dijah, C., \& S. (2016). Penerapan model pembelajaran matematika melalui pemecahan masalah untuk meningkatkan penalaran matematis siswa Kelas XA SMA Al-Musilum. Jurnal Review Pembelajaran Matematika, 1(1), 17-30.

Mairisiska, T, Sutrisno, \& A. (2014). Pengembangan perangkat pembelajaran berbasis TPACK pada materi sifat koligatif larutan untuk meningkatkan keterampilan berpikir kritis siswa. Edu Sains, 3(1), 28-37.

Malik, S., Rohendi, D., \& Widiaty, I. (2018). Technological pedagogical content knowledge (TPACK) with information and communication technology (ICT) integration. Advances in Social Science, Education and Humanities Research, 299, 498-503.

Mishra, P., \& Koehler, M. J. (2006). Technological pedagogical content knowledge: A framework for teacher knowledge. Teachers College Record, 108(6), 1017-1054.

Muhammad, G., M, Septian, A, \& Sofa, M., I. (2018). Penggunaan model pembelajaran creative problem solving untuk meningkatkan kemampuan pemecahan masalah Matematis Siswa. Jurnal Mosharafa, 7(3), 315-325.

Mullis, I. V. S., Martin, M. O., Foy, P., \& Hooper, M. (2016). International Mathematics Achievement.

Muslich, M. (2007). KTSP Pembelajaran Berbasis Kompetensi dan Kontekstual. Jakarta: Bumi Aksara.

NCTM. (2000). Principles and Standards for School Mathematics. Retrieved from www.nctm.org

Nur, A. S., \& Palobo, M. (2018). Profil kemampuan pemecahan masalah matematika siswa ditinjau dari perbedaan gaya kognitif dan gender. Kreano : Jurnal Matematika KreatifInovatif, 9(2), 139-148.

Nur, I., Udiyah, M., \& Pujiastutik, H. (2017). Penerapan model pembelajaran creative problem solving (CPS) terhadap kemampuan pemecahan masalah IPA kelas VII SMP Negeri 2 Tuban. Proceeding Biology Education Conference, 14(1), 540-544.

Nursiami, S, \& S. (2015). Keefektifan model pembelajaran creative problem solving berbantuan flash interaktif terhadap hasil belajar. Jurnal Inovasi Pendidikan Kimia, 9(1), 1440-1449.

OECD. (2016). PISA 2015 Assessment and Analytical Framework.

Partayasa, W., Suharta, I ., G., P., \& Suparta, I. (2020). Pengaruh model creative problem solving (CPS) berbantuan video pembelajaran terhadap kemampuan pemecahan masalah ditinjau dari minat wayan. Jurnal Nasional Pendidikan Matematika, 4(1), 168-179.

Paryanto, A., \& Kurniasih, N. (2020). Eksperimentasi model pembelajaran kooperatif rotating trio exchange (RTE) dan means ends analysis (MEA) terhadap hasil belajar siswa kelas VIII SMPN 10 purworejo tahun pelajaran 2019/2020. Prosiding Sendika, 6(2), 55-61. 
Pepkin, K. L. (2014). Creative Problem Solving in Math.

Pramestika, R. A., Suwignyo, H., \& Utaya, S. (2020). Model pembelajaran creative problem solving pada kemampuan berpikir kreatif dan hasil belajar tematik siswa sekolah dasar. Jurnal Pendidikan: Teori, Penelitian Dan Pengembangan, 5(3), 361-366.

Puccio, G.,J., Mary C.,Marie, M. (2005). Current developments in creative problem solving for organizations: A focus in thinking skills and styles. The Korean Jornal Of Thinking \& Problem Solving, 15(2), 43-76.

Purwaningsih, E. (2015). Potret representasi pedagogical content knowledge ( PCK ) guru dalam mengajarkan materi getaran dan gelombang pada siswa SMP. Indonesian Journal of Applied Physics, 5(1), 9-15.

Rahmadi. (2019). Technological pedagogical content knowledge ( TPACK ): Kerangka pengetahuan guru abad 21. Journal of Civics and Education Studies, 6(1), 65-74.

Rahmadi, I. F., Hayati, E., \& Nursyifa, A. (2020). Comparing pre- service civic education teachers' TPACK confidence across course modes: Insights for future teacher education programs. Research in Social Science and Technology, 5(2), 113-133.

Rahmani, W., W. (2018). Meningkatkan kemampuan pemecahan masalah matematis siswa melalui media tangram. FIBONACCI: Jurnal Pendidikan Matematika Dan Matematika, $4(1), 17-24$.

Siswono, T. Y. E. (2016). Proses berfikir kreatif siswa dalam memecahkan dan mengajukan masalah matematika. Jurnal Ilmu Pendidian, 15(1), 60-68.

Sugianto, S., \& Wijaya, P., A. (2018). Penerapan model pembelajaran CPS dengan bantuan modul elektronik terhadap motivasi belajar dan kempuan berpikir kreatif di SMA Negeri 8 Pekan Baru. Jurnal PEKA, 6(1), 72-79.

Sutrisno. (2012). Kreatif Mengembangkan Aktivitas Pembelajaran Berbasis TIK. Jakarta: Gaung Persada.

Suyamto, J., \& Masykuri, M. (2020). Analisis kemampuan TPACK ( technologocal , pedagogical, and content, knowledge) guru biologi SMA dalam menyusun perangkat pembelajaran materi sistem peredaran darah. Inkuiri : Jurnal Pendidikan IPA, 9(1), 4657.

Tuithof, H., Van Drie, J., Bronkhorst, L., Dorsman, L., \& Van Tartwijk, J. (2021). Teachers ' pedagogical content knowledge of two specific historical contexts captured and compared. Educational Studies, 47(2), 1-26.

Turmuzi, M., Azmi, S., \& Hikmah, N. (2018). Penerapan model pembelajaran creative problem solving (CPS) untuk meningkatkan kemampuan pemecahan masalah mahasiswa pendidikan matematika. Jurnal Pijar MIPA, 13(1), 45-50.

Ulya. H. (2016). Profil kemampuan pemecahan masalah siswa bermotivasi belajar tinggi berdasarkan ideal problem solving. Jurnal Konseling GUSJIGANG, 2(1), 90-96. 
Waluyo, E., N. (2021). Pengembangan desain instruksional model inquiry learning teintegrasi TPACK untuk meningkatkan kemampuan pemecahan masalah. Jurnal Pengembangan Pembelajaran Matematika, 3(1), 1-11.

Waluyo, E., Supiyati, S., \& Halqi, M. (2020). Mengembangkan perangkat pembelajaran kalkulus integral berbasis model pengajuan dan pemecahan masalah untuk meningkatkan kemampuan berpikir kreatif mahasiswa. Jurnal Elemen, 6(2), 357-366.

Winarti, D., Jamiah, Y., \& Suratman, D. (2017). Kemampuan pemecahan masalah siswa dalam menyelesaikan soal cerita berdasarkan gaya belajar pada materi pecahan di SMP. Jurnal Pendidikan Dan Pembelajaran Khatulistiwa, 6(6), 1-9.

Yanti, M., Sudia M., \& Arapu, L. (2019). Pengaruh model pembelajaran mind mapping terhadap kemampuan berpikir kreatif matematis peserta didik kelas VIII SMP Negeri 8 Konawe Selatan. Jurnal Penelitian Pendidikan Matematika, 7(3), 71-84. 